\title{
Investigating the Impact of Gender Differences on Alleviating Distrust via Electronic Word-of-Mouth
}

\author{
Liu, Albert Fei; Xiao, Bo Sophia; Lim, Eric T. K.; Tan, Chee-Wee
}

\author{
Document Version \\ Accepted author manuscript \\ Published in: \\ Industrial Management \& Data Systems
}

DOI:

10.1108/IMDS-04-2016-0150

Publication date:

2017

License

Unspecified

Citation for published version (APA):

Liu, A. F., Xiao, B. S., Lim, E. T. K., \& Tan, C-W. (2017). Investigating the Impact of Gender Differences on Alleviating Distrust via Electronic Word-of-Mouth. Industrial Management \& Data Systems, 117(3), 620-642. https://doi.org/10.1108/IMDS-04-2016-0150

Link to publication in CBS Research Portal

\section{General rights}

Copyright and moral rights for the publications made accessible in the public portal are retained by the authors and/or other copyright owners and it is a condition of accessing publications that users recognise and abide by the legal requirements associated with these rights.

\section{Take down policy}

If you believe that this document breaches copyright please contact us (research.lib@cbs.dk) providing details, and we will remove access to the work immediately and investigate your claim.

Download date: 26. Apr. 2023

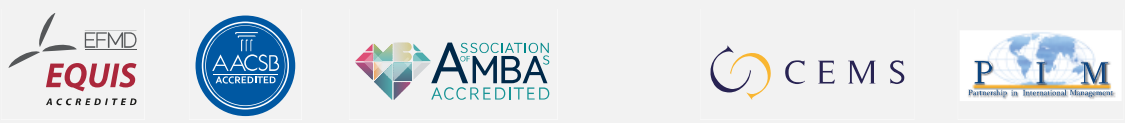




\title{
Investigating the Impact of Gender Differences on Alleviating Distrust via Electronic Word-of-Mouth
}

\author{
Albert Fei Liu, Bo Sophia Kiao, Eric T. K. Lim, and Chee Wee Tan
}

Journal article (Accepted manuscript)

CITE: Investigating the Impact of Gender Differences on Alleviating Distrust via Electronic Word-of-Mouth. / Liu, Albert Fei; Xiao, Bo Sophia; Lim, Eric T. K.; Tan, Chee-Wee. In: Industrial Management \& Data Systems, Vol. 117, No. 3, 2017, p. 620-642.

This article is [0 Emerald Group Publishing and permission has been granted for this version to appear here: https://research.cbs.dk/en/publications/investigating-the-impact-of-gender-differences-on-alleviating-dis.

Emerald does not grant permission for this article to be further copied/distributed or hosted elsewhere without the express permission from Emerald Group Publishing Limited.

DOI: 10.1108/IMDS-04-2016-0150

Uploaded to Research@CBS: December २०1८ 


\title{
Investigating the Impact of Gender Differences on Alleviating Distrust via Electronic Word-of-Mouth
}

\author{
Fei Liu \\ Department of Digitalization, Copenhagen Business School \\ Copenhagen, Denmark \\ Bo Xiao \\ Information Technology Management Department, Shidler College of Business, \\ University of Hawai'i at Mānoa, Honolulu, Hawaii, USA \\ Eric T.K. Lim \\ School of Information Systems and Technology Management \\ University of New South Wales, Sydney, Australia

\section{Chee-Wee Tan} \\ Department of Digitalization, Copenhagen Business School \\ Copenhagen, Denmark
}

Accepted at Industrial Management and Data Systems (IMDS).

Please do not quote or cite without permission. Comments are welcome.

Please address all correspondence to the first author. 


\title{
Investigating the Impact of Gender Differences on Alleviating Distrust via Electronic Word-of-Mouth
}

\begin{abstract}
Purpose - By delineating electronic word-of-mouth (e-WOM) into numerical rating and opinionated review, we advance a research model that articulates how the provision of e-WOM can aid in alleviating consumers' distrust of online service providers, a key determinant in the former's adoption of the latter. We also endeavor to uncover the role gender plays in moderating the aforementioned relationship between eWOM and distrust.
\end{abstract}

Design/methodology/approach - The research model was validated via a field survey administered on 115 college students and faculty members, who had been exposed to a custom developed online restaurant review website. SmartPLS 2.0.M3 was employed to verify both the measurement and structural properties of our research model.

Findings - Distrust reduces male consumers' perceptions of usefulness and ease of use towards an online service provider while increasing their adoption intention. For their female counterparts, distrust reduces both perceived ease of use and adoption intention for an online service provider. Additionally, for male consumers, only opinionated review aids in alleviating distrust. Conversely, both numerical rating and opinionated review aid in alleviating the distrust of female consumers. Moreover, in contrast to their female counterparts, male consumers are less susceptible to the influence of cognitive dissonance between numerical rating and opinionated review.

Research implications - This study integrates distrust with the Technology Acceptance Model (TAM) in an attempt to gain a deeper appreciation of technology acceptance behavior. Furthermore, this study builds on the Confirmation Bias Theory to delineate e-WOM into numerical rating and opinionated review in order to better explicate variations in how males and females react to these two distinct forms of e-WOM. Consistent with the Cognitive Dissonance Theory, our distinction between numerical rating and 
opinionated review enables further exploration of the impact of cognitive dissonance between these two forms of e-WOM on male and female consumers' distrust of online service providers. Finally, this study unveils contrasting conflict resolution strategies adopted by male and female consumers to cope with cognitive dissonance in e-WOM.

Practical implications - Findings from this study yield prescriptions for practitioners in terms of how eWOM can be harnessed to alleviate consumers' distrust of online service provider. Whereas it is crucial for online service providers to draw on opinionated review to reduce distrust for male consumers, numerical rating should be emphasized for female consumers. This study also sensitizes practitioners to the drawback of providing both numerical rating and opinionated review at the same time due to the potential for cognitive dissonance.

Originality/value - This study is the first to: (1) position distrust within the well-accepted TAM in order to enrich our understanding of technology acceptance behavior; (2) testify to the importance of delineating between numerical rating and opinionated review due to the possibility of cognitive dissonance between these two distinct forms of e-WOM, as well as; (3) uncover contrasting conflict resolution strategies adopted by male and female consumers to cope with cognitive dissonance in accordance with Confirmation Bias Theory.

Keywords: e-WOM, Distrust, Numerical Rating, Opinionated Review, Cognitive Dissonance, Confirmation Bias Theory 


\section{Introduction}

Prior research has attested to the pivotal role of trust in affecting consumers' evaluation of service providers across diverse online contexts, including e-commerce (Gefen and Straub, 2004; Gefen et al., 2003a; Li et al., 2015; McKnight et al., 2002; Shi and Chow, 2015), e-government (Bélanger and Carter, 2008; Tan et al., 2008; Warkentin et al., 2002), e-health (Andreassen et al., 2007; Hesse et al., 2005), and e-banking (Benamati et al., 2006). Consumers who trust a service provider tend to regard the latter as being competent and reliable (Gefen et al., 2003b; Pavlou and Fygenson, 2006; Pavlou, 2003), culminating in desired consumption behaviors such as adoption (Gefen et al., 2003b; Komiak and Benbasat, 2006) and retention (Sirdeshmukh et al., 2002; Valvi and Fragkos, 2012). Consequently, online service providers ${ }^{1}$ have undertaken a broad range of measures to foster and maintain consumers' trust, which include offering warranties (Aiken and Boush, 2006; Yen, 2006), building reputation (Biswas and Biswas, 2004; Kim et al., 2004), securing third-party endorsements (Aiken and Boush, 2006; Biswas and Biswas, 2004; Wang et al., 2004; Yen, 2006), and financing promotional advertisements (Aiken and Boush, 2006; Biswas and Biswas, 2004).

In contrast to the extensive body of research on the effects of trust on online service provision, there has been comparatively less progress in discerning the role of distrust in driving consumers' evaluation of such services, much less in devising appropriate means for alleviating the adverse impact of distrust. Prior research has testified to trust and distrust as distinct concepts that can co-exist: they neither exist as two extremes of a continuum nor are they mutually exclusive (Lewicki et al., 1998). Indeed, past studies have uncovered separate psychological mechanisms through which trust and distrust shape consumers' behavioral intentions in the context of e-commerce (Cho, 2006). Likewise, Dimoka (2010) employed functional neuroimaging (fMRI) techniques to examine trust and distrust as distinguishable at a neurological level. As compared to trust which captures one's “positive expectation of a partner's beneficial

\footnotetext{
${ }^{1}$ In this study, we take a broad view of online service providers in that they encompass any website, which engages in the delivery of digital services.
} 
conduct" (Cho, 2006, p. 26), distrust reflects one's "positive expectation of injurious action" (Luhmann, 1979). Consequently, research should go beyond the simple treatment of distrust as the opposite of trust when investigating its adverse effect on online service providers as well as the subsequent means employed to alleviate such effect. Furthermore, it can be important for online service providers to address consumers' distrust since the adverse impact of distrust tend to be much more immediate and intensive (Dimoka, 2010). In this study, we aim to bridge the abovementioned knowledge gap by exploring the effects of distrust on consumers' evaluation of online service providers and introducing electronic word-of-mouth (e-WOM) as a viable means of mitigating the negative impact of distrust.

The advent of the Web 2.0 infrastructure and the ensuing growth of e-WOM constitute an attractive option for online service providers to cultivate consumers' trust in digital environments. By inducing social presence, e-WOM compensates for the absence of social cues and continuous reciprocity within digital environments (Gefen, 2000; Reichheld and Schefter, 2000), thereby laying the foundation for trust building efforts (Gefen and Straub, 2004). In addition, e-WOM possesses three major advantages that bolster its potential for alleviating distrust in digital environments. First, e-WOM is often timely and relevant due to frequent updating (Ertimur and Gilly, 2012; Lawrence et al., 2013; Thompson and Malaviya, 2013). Second, e-WOM tends to draw consumers' attention because it is often deemed as a dependable source of information (Jabr and Zheng, 2013). According to Channel Advisor (2010), nearly 92\% of consumers prefer to consult e-WOM when making purchases. Finally, most consumers (i.e., 92.3\%) regard e-WOM as more trustworthy than any other form of communication from online service providers (eMarketer, 2010).

Despite the aforementioned advantages of e-WOM, discrepancy in its various forms may give rise to uncertainty and erodes its capability in alleviating distrust. e-WOM often manifests in both quantitative (e.g., like/dislike or five-star rating) and qualitative (e.g., comments or written reviews) formats (Mudambi and Schuff, 2010). Past studies have hinted at the importance of distinguishing between numerical rating and opinionated review. Whereas numerical rating is a concise indicator of a consumer's attitude towards a product or service (Fiske and Taylor, 2013), opinionated review supplies contextual information and reasoning behind the consumer's opinion. For this reason, opinionated review demands extra effort to 
process and leaves room for subjective interpretation (Park and Kim, 2008; Park and Lee, 2008). In line with the Cognitive Dissonance Theory (Cooper, 2007; Festinger, 1962, 2010), conflicts between numerical rating and opinionated reviews can result in cognitive strain (Kahneman, 1973), which in turn compels consumers to seek out discrete conflict resolution strategies in order to restore their internal consistency (Festinger, 1962, 2010). Yet, few studies have examined the overall influence of e-WOM on consumers' distrust towards online service providers, let along investigating the influence of different forms of e-WOM (cf. Sparks and Browning 2011). By differentiating between numerical rating and opinionated review, we attempt to disentangle the effects caused by cognitive dissonance in e-WOM on consumers' distrust of online service providers.

Gender differences inherent to information processing and conflict resolution have been advocated in past studies (Chung and Monroe, 1998; Yeh et al., 2012). The Theory of Confirmation Bias holds that information should be divided into two main categories (i.e., confirming information and disconfirming information) according to whether the information confirms or disconfirms a decision maker's hypotheses (Meyers-Levy and Maheswaran, 1991; Meyers-Levy, 1986). Building on the Theory of Confirmation Bias, prior research found that when confronted with conflicting information, males tend to focus on confirming information whereas females are more likely to rely on disconfirming information (Chung and Monroe, 1998). Nevertheless, there is a scarcity of research that explores gender differences in conflict resolution strategies when consumers are faced with incongruent information in e-WOM (cf. Yeh et al. 2012).

Whereas prior research is centered on the volume, valence, and dispersion of e-WOM (Aggarwal et al., 2012), this study extends extant literature by answering the following research questions: (1) How does e-WOM in the form of numerical rating and opinionated review affect consumers' distrust of online service providers? (2) Do consumers' perceptions of dissonance between numerical rating and opinionated review shape their distrust of online service providers? (3) What is the impact of gender on the relationship between e-WOM and consumers' distrust of online service providers?

The remainder of the paper is organized as follows. Section 2 offers an overview of related work. In Section 3, we construct our research model and develop testable hypotheses. Section 4 describes the 
methodological procedure for data collection and analysis. Our analytical results are then presented in Section 5. Finally, in Section 6, we conclude by discussing the theoretical and practical implications of our empirical findings. We also highlight potential limitations of the study to be taken into consideration together with avenues for future research.

\section{Related Work}

\subsection{The Role of e-WOM in Trust and Distrust}

Trust is the "belief that the trustee will act cooperatively to fulfill the trustor's expectations without exploiting its vulnerabilities" (Pavlou and Fygenson, 2006, p. 123), a belief founded on the competence, integrity, and benevolence of the trustee (Gefen et al., 2003b; Pavlou and Fygenson, 2006). Whereas competence refers to the "trustee's ability to perform as expected by the trustor" (Pavlou and Fygenson, 2006, p. 123), integrity refers to the trustee's honesty in keeping his/her promises (Pavlou and Fygenson, 2006), and benevolence refers to the trustee's unwillingness to engage in opportunistic behavior (Pavlou and Fygenson, 2006). Prior research has integrated trust with TAM because even though perceived usefulness and perceived ease of use are salient drivers of technology acceptance, neither constitutes ample grounds to rule out the possibility of opportunistic behavior during economic transactions (Gefen et al., 2003b). Consequently, trusting beliefs play a critical role in increasing consumers' intention to transact with online service providers (Bart et al., 2005; Gefen and Straub, 2003; Gefen et al., 2003b; Van der Heijden et al., 2003; Koh et al., 2012; Mukherjee and Nath, 2007; Ngai et al., 2015). Because consumers' trust in an online service provider lowers uncertainty, it aids in enhancing consumers' perceptions of usefulness of the service provider (Gefen et al., 2003b), thereby amplifying the expected utility to be gained from the transaction (Fukuyama, 1995). Moreover, due to reduced uncertainty, transactional costs are reduced because trusting consumers do not have to expend unnecessary resources to monitor the online service provider and take precautions to safeguard against opportunism (Fukuyama, 1995), thereby enhancing their perceptions of ease of use towards the service provider (Pavlou, 2003). 
Yet, trust building process is often hindered in digital environments due to the absence of social context (Gefen, 2000; Kollock, 1999; Reichheld and Schefter, 2000). To compensate for the lack of social cues and bolster consumers' trust, Gefen and Straub (2004) proposed that online service providers can project social presence, which refers to "the extent to which a medium allows users to experience others as being psychologically present" (p. 11). Past studies have alluded to the effectiveness of e-WOM in inducing social presence and increasing the trustworthiness of online service providers. Dellarocas (2003) as well as Gefen and Straub (2004) discovered that the provision of e-WOM increased the trustworthiness of online service providers even under conditions of reviewer anonymity (Pan and Chiou 2011). Similarly, Jabr and Zheng (2013) illustrated that opinions from peer consumers were trusted more than firm-sponsored communication. Lee et al. (2009) further testified to the existence of a spill-over effect from trust in eWOM onto the hosting website. They found that the provision of e-WOM by an online service provider significantly increased consumers' trust in the service provider (Lee et al., 2009).

Distrust, defined as "a positive expectation of injurious action" (Luhmann, 1979), captures individuals' apprehension that their vulnerabilities will be exploited by an incompetent and irresponsible partner with ill intentions (Kramer, 1999; Lewicki et al., 1998; Sitkin and Roth, 1993). For this reason, distrust should be treated as a qualitatively distinct belief from that of trust: distrust is not merely the absence of trust, but rather, it reflects cynicism, fear and suspicion (Cho, 2006). Indeed, several studies have validated the distinction between trust and distrust. Lewicki et al. (1998) refuted the conventional view of distrust as the reverse of trust by portraying trust and distrust as two perpendicular dimensions that can coexist in reality. Guha et al. (2004), in conducting an experiment on a large network comprising 130,000 individuals, observed that the inclusion of distrust in their research model resulted in more accurate prediction of trust between any two individuals within the network. Likewise, based on a survey of 881 ecommerce consumers, Cho (2006) discovered that benevolence was more likely to induce trust whereas competence tended to alleviate distrust. Cho (2006) further showed that, while distrust outweighed trust in shaping consumers' behavioral intention whereas, trust played a more instrumental role in regulating their commitment. Employing fMRI technique to map out participants' brain activities when they were exposed 
to online service providers exhibiting varying degrees of trust and distrust, Dimoka (2010) was able to separate trust from distrust at the neurological level. Specifically, trust was shown to be connected to brain regions associated with reward, prediction, and uncertainty whereas distrust was found to be linked to brain regions associated with intense emotions and fear for loss (Dimoka, 2010). Due to discrepancies in active brain areas, trust and distrust exhibited differences with respect to the type (i.e., autonomic versus intentional) and nature (i.e., collected versus frenzied) of response as well as the time horizon (long-term versus short-term) (Dimoka, 2010). Conceivably, alleviating distrust could be seen as a more purposeful activity for online service providers. Specifically, by alleviating consumers' distrust, online service providers can effectively and efficiently prevent consumers' undesirable behavior. In this study, we endeavor to uncover the consequences of distrust and how these consequences can be alleviated through the provision of e-WOM.

\section{Theory Development}

In this study, we subscribe to the Technology Acceptance Model (TAM) as our theoretical lens, while simultaneously drawing inspiration from extant literature on distrust, social presence, cognitive dissonance, and confirmation bias to construct our research model and formulate testable hypotheses (see Figure 1).

- Insert Figure 1 about here -

\subsection{Technology Acceptance Model and Distrust}

According to TAM, consumers' receptivity towards technology (e.g., online service providers) is dictated by two core beliefs: perceived usefulness, which refers to an individual's assessment of the utility to be gained from using a technology, and perceived ease of use, which is defined as an individual's estimation of the cognitive effort required to utilize the technology (Gefen et al., 2003b). Because the relationships among the focal constructs of TAM (Davis, 1989; Davis et al., 1992) have received rigorous validation in prior research (Gefen and Straub, 2003, 2004; Gefen et al., 2003b; Kim, 2012; Pavlou and Fygenson, 2006; Ulbrich et al., 2011), we hypothesize that:

Hypothesis 1: A consumer's perceived usefulness of an online service provider positively influences his/her intention to transact with the service provider. 
Hypothesis 2: A consumer's perceived ease of use of an online service provider positively influences his/her perceived usefulness of the service provider.

Hypothesis 3: A consumer's perceived ease of use of an online service provider positively influences his/her intention to transact with the service provider.

Past studies on e-commerce have integrated trust with TAM because neither perceived usefulness nor perceived ease of use is adequate in addressing consumers' concerns for opportunistic behavior during economic transactions (Gefen et al., 2003b). Trust plays a critical role in increasing consumers' intention to transact with online service providers (Bart et al., 2005; Gefen and Straub, 2003; Gefen et al., 2003b; Van der Heijden et al., 2003; Koh et al., 2012; Mukherjee and Nath, 2007; Ngai et al., 2015). Unlike trust, which encourages consumers to accept vulnerability when interacting with an online service provider, distrust induces consumers' negative emotions and fear towards an online service provider (Dimoka, 2010). Distrust thus diminishes consumers' behavioral intentions to transact with online service providers due to the former's desire to protect themselves from the latter's malevolent practices (Cho, 2006). In addition, distrust compels consumers to automatically avoid untrustworthy online service providers due to their inherent fear of economic loss and social harm (Dimoka, 2010). We therefore hypothesize that:

Hypothesis 4: A consumer's distrust of an online service provider negatively influences his/her intention to transact with the service provider.

Distrusting consumers expect their transactions with an online service provider to result in economic loss (Dimoka, 2010), hence lowering their perceptions of usefulness of the service provider (Gefen et al., 2003b). This differs from how trust influences consumers' perceived usefulness, where consumers' trust in an online service provider reduces uncertainty and amplifies the expected utility to be gained from interactions (Fukuyama, 1995), which in turn enhances their perceptions of usefulness of the service provider (Cao et al., 2005; Gefen et al., 2003b). We therefore hypothesize that:

Hypothesis 5: A consumer's distrust of an online service provider negatively influences his/her perceived usefulness of the service provider.

Trusting consumers could devote less resources to monitoring online service providers and staying vigilant against opportunism (Fukuyama, 1995), thereby culminating in perceptions of ease of use (Pavlou, 2003). Different from trusting consumers, distrusting ones invest in defensive and preventive actions in 
response to their anticipation of undesirable conduct from an online service provider (Cho, 2006). For this reason, consumers' interactions with an untrustworthy online service provider entail extra costs, which in turn lead to a reduced sense of ease of use towards the service provider. We therefore hypothesize that:

Hypothesis 6: A consumer's distrust of an online service provider negatively influences his/her perceived ease of use of the service provider.

\subsection{Effect of e-WOM on Distrust}

Prior research investigating the effect of e-WOM on distrust suggests that numerical rating should be distinguished from opinionated review (Mudambi and Schuff, 2010). Specifically, numerical rating often takes the form of ordinal rating (e.g., certain number of stars out of five or ten). Because it is precise and specific, numerical rating can be especially effective when consumers wish to have a simplified means of eliminating potentially incompetent and/or malevolent online service providers (Fiske and Taylor, 2013). Numerical rating also caters to categorical thinking (Macrae and Bodenhausen, 2001) and assists consumers in isolating undesirable options (Lee et al., 2009; Sparks and Browning, 2011). Numerical rating thus helps the consumers steer away from incompetent online service providers or those with ill intentions (Kramer, 1999; Lewicki et al., 1998; Sitkin and Roth, 1993), and in turn suppresses their emotions relating to distrust, including cynicism, fear, and suspicion (Cho, 2006). On the other hand, opinionated review is usually in the form of written comments, offering background information and contextual reasoning behind each reviewer's opinion. Opinionated review thus necessitates greater cognitive effort to consume and also leaves room for personal interpretation (Park and Kim, 2008; Park and Lee, 2008). Nonetheless, consumers often regard opinionated review as being more dependable (Jabr and Zheng, 2013) and rely on such reviews to rule out malevolent online service providers, especially for those who are willing to expend the necessary effort to inspect and interpret the arguments put forth by the reviewers (Park and Kim, 2008; Park and Lee, 2008). Consequently, both forms of e-WOM (i.e., numerical rating and opinionated review) are beneficial in alleviating consumers' distrust in an online service provider (Lee et al., 2009). We therefore hypothesize that:

Hypothesis 7: e-WOM in the form of numerical rating provided by an online service provider negatively influences a consumer's distrust of the service provider. 
Hypothesis 8: e-WOM in the form of opinionated review provided by an online service provider negatively influences a consumer's distrust of the service provider.

\subsection{Cognitive Dissonance}

Cognitive dissonance refers to a situation where an individual is confronted with conflicting attitudes, beliefs, or behaviors (Cooper, 2007; Festinger, 1962, 2010). Cognitive dissonance theory holds that individuals strive to regain internal consistency when faced with conflicting information (Cooper, 2007; Festinger, 1962, 2010). Extrapolated to digital environments, when presented with conflicting information from an online service provide, consumers tend to resolve this dissonance by altering their beliefs about the trustworthiness of this service provider (Festinger, 1962, 2010).

Numerical rating is quantitative in nature whereas opinionated review consists of qualitative information. While numerical rating represents an overall attitude, opinionated review contains detailed reasoning behind an expressed opinion. It is hence not unusual for numerical rating and opinionated review to be inconsistent with each other, even when they possess the same valence. Discrepancies between numerical rating and opinionated review, when detected by consumers, may be difficult to reconcile. Therefore, even though both numerical rating and opinionated review alleviate consumers' distrust of an online service provider (Jabr and Zheng, 2013; Sparks and Browning, 2011), dissonance between these two forms of e-WOM may trigger consumers' skepticism of the service provider's intent. The positive effect of cognitive dissonance in intensifying consumers' feeling of distrust is likely to spill over to the hosting site (Lee et al., 2009), especially when both forms of e-WOM are displayed side by side. We therefore hypothesize that:

Hypothesis 9: A consumer's perception of cognitive dissonance between numerical rating and opinionated review offered by an online service provider positively influences his/her distrust of the service provider.

\subsection{Gender Difference in Confirmation Bias}

A fundamental gender difference identified in psychology and cognition literature is that males are driven by agentic goals whereas females follow communal goals (Carlson, 1971, 1972). In other words, males like to maintain self-esteem and pursue individualistic achievements whereas females are more 
concerned with collective harmony and welfare (Chung and Monroe, 1998). This gender difference in ego functioning translates into variations in confirmation bias between males and females (Meyers-Levy, 1986).

According to the Confirmation Bias Theory (Meyers-Levy, 1986), information can either confirm or disconfirm decision makers' hypotheses. The co-occurrence of two (potentially inconsistent) pieces of information exacerbates decision makers' cognitive stress, resulting in gender-specific coping strategies. More specifically, male decision makers, due to their natural inclination towards maintaining agency and self-esteem, tend to rely on information that affirms their hypotheses and disregard information that invalidates these hypotheses (Chung and Monroe, 1998). When evaluating an online service provider, male consumers tend to form their own hypotheses of the corresponding service provider before turning to reviewers' comments to confirm these hypotheses (Chung and Monroe, 1998). Conversely, female decision makers care less about validating their own hypotheses; rather, they seek to minimize incongruity by paying attention to information that disconfirms their hypotheses (Chung and Monroe, 1998). Female consumers are thus more likely to be swayed by reviewers' opinions when evaluating a specific online service provider.

Numerical rating and opinionated review tend to disconfirm and confirm consumers' hypotheses respectively. Numerical rating is an indication of a reviewer's overall personal attitude (Fiske and Taylor, 2013). For this reason, consumers who prefer adhering to other reviewers' opinions while disregarding their own hypotheses about an online service provider are more likely to concentrate on numerical rating. Because numerical rating mainly serves the role of disconfirming a consumer's hypotheses, it is likely to be valued by those who prefer dissenting opinions over contextual justification. We hence posit disconfirmation as a defining characteristic of numerical rating. Conversely, opinionated review often delivers facts and reasoning behind an expressed opinion, opening up room for consumers' selective interpretation (Park and Kim, 2008; Park and Lee, 2008). In this sense, consumers who aim to confirm their own hypotheses can often find supporting evidence from opinionated review. We therefore postulate confirmation as a defining characteristic of opinionated review.

Due to contrasting characteristics of numerical rating and opinionated review in confirming or disconfirming consumers' hypotheses respectively, we expect that different genders will prefer one form 
of e-WOM to the other whenever perceptions of cognitive dissonance arises between these two forms of eWOM. Particularly, when encountering discrepancy between numerical rating and opinionated review, male consumers will shift their focus to the opinionated review while discounting the numerical rating. In this case, the negative influence of opinionated review on distrust would be reinforced while the negative relationship between numerical rating and distrust would be attenuated. On the other hand, when faced with inconsistent numerical rating and opinionated review, female consumers will place greater emphasis on numerical rating as a conflict coping strategy. For female consumers, perceptions of cognitive dissonance between numerical rating and opinionated review hence reinforce the negative effect of numerical rating on distrust while attenuating the negative relationship between opinionated review and distrust. We therefore hypothesize that:

Hypothesis 10a: For male consumers, their perceptions of cognitive dissonance between numerical rating and opinionated review offered by an online service provider attenuate the negative relationship between numerical rating and their distrust of the service provider.

Hypothesis 10b: For female consumers, their perceptions of cognitive dissonance between numerical rating and opinionated review offered by an online service provider reinforce the negative relationship between numerical rating and their distrust of the service provider.

Hypothesis 11a: For male consumers, their perceptions of cognitive dissonance between numerical rating and opinionated review offered by an online service provider reinforce the negative relationship between opinionated review and their distrust of the service provider.

Hypothesis 11b: For female consumers, their perceptions of cognitive dissonance between numerical rating and opinionated review offered by an online service provider attenuate the negative relationship between opinionated review and their distrust of the service provider.

\section{Methodology}

To validate the hypotheses in our research model, we administered a field survey on respondents, who were directed to a custom-developed online restaurant review website. Through an artificial website, we can familiarize respondents with both numerical rating and opinionated review, thereby circumventing the challenges respondents may have in recalling their own experience with e-WOM when answering survey questions. To ensure the realism of our own artificial website, we populated the website with 
268,000 real online consumer reviews posted by nearly 91,000 diners for 1,079 restaurants in the San Francisco area, which were extracted through web scraping.

\subsection{Development of Survey Measures}

Measurement items for both numerical rating and opinionated review were developed in accordance with standard psychometric procedures (Moore and Benbasat, 1991). Measures for TAM constructs, including perceived usefulness, perceived ease of use, and adoption intention, were adapted from past studies (e.g., Gefen et al. 2003b). Items for measuring distrust were elicited from Cho (2006) whereas those for measuring cognitive dissonance were obtained from Festinger (2010). Table 1 depicts the list of measurement items for this study.

- Insert Table 1 about here -

\subsection{Field Survey Procedures}

At the start of each survey session, respondents were asked to provide their demographic information. They were then directed to our online review website and requested to complete a structured, goal-oriented restaurant selection task (i.e., selecting a restaurant for a fictional friend) as well as an unstructured, exploratory restaurant selection task (i.e., selecting a restaurant for yourself) (Browne et al., 2007; Nadkarni and Gupta, 2007) (see Appendix A for the task scenarios). Respondents were instructed to make their selection by going through the numerical ratings and opinionated reviews available for each restaurant. Upon the completion of both tasks, respondents were presented with an online survey questionnaire that measured their perceptions with regards to the provision of numerical rating and opinionated review, the cognitive dissonance between the two forms of e-WOM, their distrust of the website as well as their perceived usefulness, perceived ease of use, and adoption intention towards the website. 115 undergraduate students and faculty members from a large North American university participated in the field survey. Descriptive statistics of the sample are summarized in Table 2.

- Insert Table 2 about here -

\subsection{Measurement Model}


As the data was gathered via a single survey questionnaire, common method bias could be a potential threat to the internal validity of our study. To control for common method bias, we performed Harman's (1976) one-factor extraction test by conducting Exploratory Factor Analysis (EFA) of the 24 variables. Four components with eigenvalues greater than 1.00 emerged from the EFA with no single factor accounting for more than $50 \%$ of the total variance explained (Schriesheim, 1979). This implies that our data analysis is unlikely to be plagued by common method bias.

To validate our measurement model, we assessed the reliability, internal consistency as well as the convergent and discriminant validity of all the measurement items. Item reliability was evaluated by examining the factorial loadings of the measures on their respective latent constructs. Since all loadings exceed 0.7 , satisfactory item reliability is assured (see Table 1). Internal consistency was established by computing Cronbach's alpha, Composite Reliability (CR), and the Average Variance Extracted (AVE) for each latent construct in our research model (Fornell and Larcker, 1981; Nunnally and Bernstein, 1994). Results indicate good internal consistency as indictors surpass recommended thresholds for each construct (see Table 3). Besides, a careful scrutiny of the loading and cross-loading matrix reveals that no item loads higher on a construct than the one it is intended to measure. Furthermore, the square root of AVE for each construct is greater than the correlations of the construct with every other construct (see Table 3). Taken together, these statistics point to sufficient convergent and discriminate validity.

- Insert Table 3 about here -

\subsection{Structural Model}

Partial Least Square (SmartPLS 2.0 M3) was employed to validate our structural model (Chin, 1998). PLS analysis allows us to simultaneously analyze the direction and strength of each hypothesized relationship (Wixom and Watson, 2001). We utilized the bootstrapping algorithm provided by SmartPLS 2.0 M3 to calculate the $t$-value for each hypothesized relationship with the default settings (i.e., individual sign changes, 500 cases, and 500 samples). To validate our hypotheses pertaining to gender difference, we split our dataset according to respondents' gender and analyzed the structure model not only with male and 
female samples, but also with the combined sample. Figure 2 illustrates the analytical results for the structural model based on all three datasets.

- Insert Figure 2 about here -

Consistent with prior research, perceived usefulness partially mediates the positive effect of perceived ease of use on intention to adopt the website for both males and females. Perceived usefulness heightens adoption intention $\left(\beta_{\text {male }}=0.777, p<0.01 ; \beta_{\text {female }}=0.653, p<0.01 ; \beta_{\text {total }}=0.652, p<0.01\right)$ whereas perceived ease of use positively influences both perceived usefulness $\left(\beta_{\text {male }}=0.871, p<0.01 ; \beta_{\text {female }}=0.883\right.$, $\left.p<0.01 ; \beta_{\text {total }}=0.863, p<0.01\right)$ and adoption intention $\left(\beta_{\text {male }}=0.185, p<0.01 ; \beta_{\text {female }}=0.172, p<0.01\right.$; $\beta_{\text {total }}=0.268, p<0.01$ ), thus corroborating Hypothesis 1 to 3 . Nonetheless, the effects of distrust diverge for male and female consumers. For male consumers, whereas distrust reduces both perceived usefulness $\left(\beta_{\text {male }}=-0.091, p<0.05\right)$ and perceived ease of use $\left(\beta_{\text {male }}=-0.279, p<0.01\right)$, it increases their adoption intention $\left(\beta_{\text {male }}=0.058, p<0.01\right)$. For female consumers, on the other hand, distrust reduces both perceived ease of use $\left(\beta_{\text {female }}=-0.584, p<0.01\right)$ and adoption intention $\left(\beta_{\text {female }}=-0.202, p<0.01\right)$ while having no significant influence on perceived usefulness $\left(\beta_{\text {female }}=0.020, p>0.05\right)$. Hypotheses 4 and 5 are only partially supported whereas Hypothesis 6 is fully supported. Results suggest that for female consumers, their distrust of an online service provider has little influence on their perceived usefulness of the service provider. A plausible explanation for the unexpected positive relationship between distrust and adoption intention could be that male consumers are inclined to validate their own hypothesis regarding the untrustworthiness of an online service provider by transacting with the service provider (cf. Chung and Monroe, 1998).

Our structural model also reveals the impact of e-WOM in shaping consumers' distrust of an online service provider. Results from the male sample demonstrate that only opinionated review contributes to the alleviation of distrust $\left(\beta_{\text {male }}=-0.375, p<0.01\right)$. Neither numerical rating $\left(\beta_{\text {male }}=0.036, p>0.05\right)$ nor cognitive dissonance $\left(\beta_{\text {male }}=-0.046, p>0.05\right)$ affects distrust for male consumers significantly. Conversely, results from the female sample demonstrate that both numerical rating $\left(\beta_{\text {female }}=-0.155, p<0.01\right)$ and opinionated review $\left(\beta_{\text {female }}=-0.526, p<0.01\right)$ can contribute to the alleviation of distrust. In addition, 
perceptions of cognitive dissonance between numerical rating and opinionated review tend to evoke female consumers' distrust of an online service provider $\left(\beta_{\text {female }}=0.193, p<0.01\right)$. These results partially support Hypotheses 7 and 9 while Hypothesis 8 is fully supported. Male consumers' emphasis on opinionated review in alleviating distrust lends credibility to our proposition that males tend to rely on opinionated review in confirming their hypothesis (Chung and Monroe, 1998).

Neither Hypothesis 10a nor Hypothesis 11a is supported. Contrary to our anticipation, perceptions of cognitive dissonance between numerical rating and opinionated review further weakens the insignificant positive effect of numerical rating on distrust for male consumers $\left(\beta_{\text {male }}=-0.077, p<0.01\right)$. Moreover, cognitive dissonance exerts little influence on the negative relationship between opinionated review and distrust $\left(\beta_{\text {male }}=0.332, p>0.05\right)$ for male consumers, which implies that it is unlikely for cognitive dissonance to undermine the credibility of opinionated review. These results suggest that male consumers are insensitive to the dissonance between numerical rating and opinionated review due to the dominant role of the latter in the formation of their distrust (Chung and Monroe, 1998). Conversely, both Hypotheses 10b and $11 \mathrm{~b}$ are supported. Female consumers are more susceptible to the influence of cognitive dissonance due to their focus on collective harmony and welfare (Chung and Monroe, 1998). Perceptions of dissonance between numerical rating and opinionated review reinforce the effect of the former in alleviating distrust $\left(\beta_{\text {female }}=-0.377, p<0.01\right)$ while attenuating the negative relationship between the latter and distrust $\left(\beta_{\text {female }}\right.$ $=0.941, p<0.01)$. In other words, when confronted with cognitive dissonance, female consumers tend to rely on numerical rating to alleviate their distrust of online service providers. Results from our hypotheses testing are summarized in Table 4.

- Insert Table 4 about here -

In order to demonstrate the predictive validity of our structural model, we summarized the $R^{2}$ values and $Q^{2}$ values of all four endogenous constructs in Table 5. According to Hair Jr et al. (2016), $R^{2}$ value indicates the percentage of variance in an endogenous construct that can be explained by a model, thus reflecting the model's predictive accuracy. On the other hand, $Q^{2}$ value acts as an indicator of the model's predictive relevance. It represents how well the model, which is estimated by part of the data points, predicts 
the remaining data points. The results show that, although the predictive power of our structural model in predicting perceived ease of use is relatively low (i.e., $R^{2}$ and $Q^{2}$ values are between 0.02 and 0.15 ) for male samples, it maintains satisfactory predictive accuracy and relevance across all endogenous constructs (i.e., $R^{2}$ and $Q^{2}$ values are larger than 0.15 ) (Hair Jr et al., 2016).

- Insert Table 5 about here -

\section{Discussion}

In this study, we integrate distrust with TAM to investigate the effects of providing distinct forms of e-WOM (i.e., numerical rating and opinionated review) on alleviating consumers' distrust of online service providers. Furthermore, we unravel how dissonance between numerical rating and opinionated review can induce distrust and moderate the impact of e-WOM on consumers of different genders. Findings from our field survey reveal that distrust undermines male consumers' perceptions of usefulness and ease of use towards an online service provider, while at the same time, increasing their intention to transact with the service provider. For their female counterparts, distrust reduces both perceived ease of use and adoption intention for the distrusted online service provider. Furthermore, only opinionated review aids in alleviating distrust for male consumers whereas both numerical rating and opinionated review contribute to alleviating distrust for female consumers. Interestingly, consumers in different genders react to dissonance between numerical rating and opinionated review in distinct manners. Specifically, male consumers' focus on opinionated review, due to its hypothesis confirming characteristic, leads to non-significant relationship between cognitive dissonance and distrust. Additionally, cognitive dissonance influences only the relationship between numerical rating and distrust for male consumers. On the other hand, when faced with cognitive dissonance, female consumers' distrust can be invoked. Furthermore, under such circumstances, female consumers tend to concentrate on numerical rating while discounting opinionated review due to their desire for collective harmony. Our findings suggest that males' tendency towards hypothesis confirmation overshadows their perceptions of dissonance between numerical rating and opinionated review. This finding is consistent with extant literature which shows that male decision makers usually 
exhibit a propensity for hypothesis confirming while their female counterparts do not (Chung and Monroe, 1998).

\subsection{Implications for Theory and Practice}

The present study contributes to extant literature on e-WOM in four ways. First, we draw parallels with prior research on trust in e-commerce as well as literature on the distinction between trust and distrust to explicate the role of distrust in TAM. Consistent with findings of past studies, we discovered that the role of distrust is not the opposite of trust (Cho, 2006; Dimoka, 2010). We found that distrust encourages male consumers to try out a questionable online service provider in order to confirm their suspicion. In addition, female consumers can tolerate distrust when assessing the usefulness of an online service provider. Second, this study builds on the confirmation bias theory (Meyers-Levy, 1986) to delineate between numerical rating and opinionated review as two distinct forms of e-WOM on the basis of their hypothesis disconfirming and confirming characteristics respectively. In doing so, we are able to articulate biases inherent in both male and female consumers towards various forms of e-WOM. Male consumers are inclined to rely on opinionated review whereas their female counterparts count on both forms of e-WOM. Third, our delineation between numerical rating and opinionated review allows us to explore the impact of cognitive dissonance between the two forms of e-WOM on distrust in an online service provider through the lens of cognitive dissonance theory (Cooper, 2007; Festinger, 1962, 2010). Our findings confirm cognitive dissonance as a hindrance in alleviating distrust among female consumers. Finally, guided by males' and females' distinct emphasis on agency and communion respectively (Meyers-Levy, 1986), this study unveils contrasting coping strategies adopted by males and females when they are confronted with cognitive dissonance between numerical rating and opinionated review. Particularly, male consumers tend to maintain their focus on opinionated review whereas their female counterparts tend to shift their attention away from opinionated review towards numerical rating.

Our findings also offer guidelines for practitioners to optimize the benefits of e-WOM in terms of alleviating consumers' distrust by personalizing the provision of numerical rating and opinionated review in accordance with consumers' genders. First, the present study highlights the cruciality of undertaking 
concrete initiatives to alleviate distrust among consumers over and above any trust building efforts, as the adverse impact of distrust is much more intensive and takes effect over a shorter time horizon (Dimoka, 2010). Second, this study alerts practitioners to the importance of prioritizing the provision of opinionated review for male consumers and numerical rating for female consumers in order to facilitate their respective conflict resolution strategies. By doing so, online service providers can reduce consumers' distrust more effectively. Third, the detrimental effects of cognitive dissonance on alleviating distrust can sensitize practitioners to the potential drawbacks of providing both numerical rating and opinionated review at the same time.

\subsection{Limitations and Future Research}

The present study is not without limitations. First, to maintain the parsimony of our research model while acknowledging the existence of other forms of e-WOM within extant literature (e.g., volume, valence, and dispersion) (Aggarwal et al., 2012), we opted to focus on the two forms of e-WOM: numerical rating and opinionated review. Nonetheless, we encourage future studies to investigate the influence of other forms of e-WOM. Second, by splitting our sample into male and female segments, we are able to validate the moderating effect of gender. However, the sample size for each gender segment is relatively small (i.e., 57 male samples and 58 female samples). Although future studies can increase the confidence of our model estimates by enlarging the sample size, the sample size for each gender segment in this study surpasses the minimum threshold required by SmartPLS 2.0 M3, which is five times the number of indicators of the construct that are measured by the highest number of indicators (i.e., 50) (Hair Jr et al., 2016). Third, the majority of our respondents are college students. Although students are suitable candidates for e-WOM research (McKnight et al., 2002), further studies can be conducted to validate our hypothesized relationships with a more diverse sample, thereby boosting the generalizability of our findings. Forth, due to the crosssectional nature of this study, spurious inferences for causal effect may exist.

\section{Appendix A}

\subsection{Task 1: Find a restaurant for your friend's birthday dinner}


Scenario: You are planning to visit your best friend, Peter, who lives in the Russian Hillarea of San Francisco and likes New American food, next Saturday. Peter will be having his birthday on the same day. You plan to surprise Peter during your visit by bringing him to a nice New American restaurant to celebrate his birthday. Because you are unfamiliar with the area around Russian Hill, you decide to turn to TasteSF, a newly set up online review website for restaurants in San Francisco, to choose an American (NEW) restaurant in the Russian Hill area.

\subsection{Task 2: Find a restaurant for yourself}

You are taking a trip to San Francisco next Saturday. You would like to enjoy a meal alone in a nice restaurant. Because you are unfamiliar with San Francisco, you decide to turn to TasteSF, a newly set up online review website for restaurants in San Francisco, to choose a restaurant you prefer.

\section{References}

Aggarwal, R., Gopal, R., Gupta, A. and Singh, H. (2012), "Putting money where the mouths are: The relation between venture financing and electronic word-of-mouth", Information Systems Research, INFORMS, Vol. 23 No. 3-part-2, pp. 976-992.

Aiken, K.D. and Boush, D.M. (2006), "Trustmarks, objective-source ratings, and implied investments in advertising: investigating online trust and the context-specific nature of internet signals", Journal of the Academy of Marketing Science, Springer, Vol. 34 No. 3, pp. 308-323.

Andreassen, H.K., Bujnowska-Fedak, M.M., Chronaki, C.E., Dumitru, R.C., Pudule, I., Santana, S., Voss, H., et al. (2007), "European citizens' use of E-health services: a study of seven countries", BMC Public Health, BioMed Central Ltd, Vol. 7 No. 1, p. 53.

Bart, Y., Shankar, V., Sultan, F. and Urban, G.L. (2005), “Are the drivers and role of online trust the same for all web sites and consumers? A large-scale exploratory empirical study", Journal of Marketing, American Marketing Association, Vol. 69 No. 4, pp. 133-152.

Bélanger, F. and Carter, L. (2008), "Trust and risk in e-government adoption”, The Journal of Strategic 
Information Systems, Elsevier, Vol. 17 No. 2, pp. 165-176.

Benamati, J., Serva, M.A. and Fuller, M.A. (2006), “Are trust and distrust distinct constructs? An empirical study of the effects of trust and distrust among online banking users", System Sciences, 2006. HICSS'06. Proceedings of the 39th Annual Hawaii International Conference on, Vol. 6, IEEE, p. $121 b-121 b$.

Biswas, D. and Biswas, A. (2004), "The diagnostic role of signals in the context of perceived risks in online shopping: do signals matter more on the web?", Journal of Interactive Marketing, available at: http://onlinelibrary.wiley.com/doi/10.1002/dir.20010/abstract (accessed 16 February 2015).

Browne, G.J., Pitts, M.G. and Wetherbe, J.C. (2007), “Cognitive stopping rules for terminating information search in online tasks", MIS Quarterly, Vol. 31 No. 1, pp. 89-104.

Cao, M., Zhang, Q. and Seydel, J. (2005), “B2C e-commerce web site quality: an empirical examination”, Industrial Management \& Data Systems, Emerald Group Publishing Limited, Vol. 105 No. 5, pp. $645-661$.

Carlson, R. (1971), "Sex differences in ego functioning: Exploratory studies of agency and communion.”, American Psychological Association.

Carlson, R. (1972), “Understanding women: Implications for personality theory and research", Journal of Social Issues, Wiley Online Library, Vol. 28 No. 2, pp. 17-32.

ChannelAdvisor. (2010), Through the Eyes of the Consumer: 2010 Consumer Shopping Habits Survey, available at: http://go.channeladvisor.com/rs/channeladvisor/images/us-wp-consumer-survey2010.pdf.

Chin, W.W. (1998), “Commentary: Issues and opinion on structural equation modeling”, JSTOR.

Cho, J. (2006), “The mechanism of trust and distrust formation and their relational outcomes", Journal of Retailing, Elsevier, Vol. 82 No. 1, pp. 25-35. 
Chung, J. and Monroe, G. (1998), "Gender differences in information processing: an empirical test of the hypothesis-confirming strategy in an audit context”, Accounting \& Finance, Wiley Online Library, Vol. 38 No. 2, pp. 265-279.

Cooper, J. (2007), Cognitive Dissonance: 50 Years of a Classic Theory, Sage.

Davis, F.D. (1989), "Perceived usefulness, perceived ease of use, and user acceptance of information technology", MIS Quarterly, JSTOR, pp. 319-340.

Davis, F.D., Bagozzi, R.P. and Warshaw, P.R. (1992), "Extrinsic and intrinsic motivation to use computers in the workplace1", Journal of Applied Social Psychology, Wiley Online Library, Vol. 22 No. 14, pp. $1111-1132$.

Dellarocas, C. (2003), “The digitization of word of mouth: Promise and challenges of online feedback mechanisms", Management Science, INFORMS, Vol. 49 No. 10, pp. 1407-1424.

Dimoka, A. (2010), "What does the brain tell us about trust and distrust? Evidence from a functional neuroimaging study", Mis Quarterly, Vol. 34 No. 2, pp. 373-396.

eMarketer. (2010), "Moms Place Trust in Other Consumers", available at: http://www.emarketer.com/Article/Moms-Place-Trust-Other-Consumers/1007509.

Ertimur, B. and Gilly, M.C. (2012), "So whaddya think? Consumers create ads and other consumers critique them”, Journal of Interactive Marketing, Elsevier, Vol. 26 No. 3, pp. 115-130.

Festinger, L. (1962), A Theory of Cognitive Dissonance, Vol. 2, Stanford university press.

Festinger, L. (2010), "Cognitive dissonance theory”, R. West and LH Turner, Introducing Communication Theory Analysis and Application, Vol. 4, pp. 112-128.

Fiske, S.T. and Taylor, S.E. (2013), Social Cognition: From Brains to Culture, Sage.

Fornell, C. and Larcker, D.F. (1981), "Evaluating structural equation models with unobservable variables 
and measurement error", Journal of Marketing Research, JSTOR, pp. 39-50.

Fukuyama, F. (1995), Trust: The Social Virtues and the Creation of Prosperity, Free press New York.

Gefen, D. (2000), "E-commerce: the role of familiarity and trust", Omega, Vol. 28 No. 6, pp. 725-737.

Gefen, D., Karahanna, E. and Straub, D.W. (2003a), "Inexperience and experience with online stores: the importance of TAM and trust", Engineering Management, IEEE Transactions on, Vol. 50 No. 3, pp. $307-321$.

Gefen, D., Karahanna, E. and Straub, D.W. (2003b), “Trust and TAM in online shopping: An integrated model", MIS Quarterly, Society for Information Management and The Management Information Systems Research Center, Vol. 27 No. 1, pp. 51-90.

Gefen, D. and Straub, D.W. (2003), "Managing user trust in B2C e-services", E-Service Journal, Indiana University Press, Vol. 2 No. 2, pp. 7-24.

Gefen, D. and Straub, D.W. (2004), "Consumer trust in B2C e-Commerce and the importance of social presence: experiments in e-Products and e-Services", Omega, Elsevier, Vol. 32 No. 6, pp. 407-424.

Guha, R., Kumar, R., Raghavan, P. and Tomkins, A. (2004), "Propagation of trust and distrust", Proceedings of the 13th International Conference on World Wide Web, ACM, pp. 403-412.

Hair Jr, J.F., Hult, G.T.M., Ringle, C. and Sarstedt, M. (2016), A Primer on Partial Least Squares Structural Equation Modeling (PLS-SEM), Sage Publications.

Van der Heijden, H., Verhagen, T. and Creemers, M. (2003), "Understanding online purchase intentions: contributions from technology and trust perspectives", European Journal of Information Systems, Nature Publishing Group, Vol. 12 No. 1, pp. 41-48.

Hesse, B.W., Nelson, D.E., Kreps, G.L., Croyle, R.T., Arora, N.K., Rimer, B.K. and Viswanath, K. (2005), "Trust and sources of health information: the impact of the Internet and its implications for health care 
providers: findings from the first Health Information National Trends Survey", Archives of Internal Medicine, American Medical Association, Vol. 165 No. 22, pp. 2618-2624.

Jabr, W. and Zheng, E. (2013), "Know yourself and know your enemy: An analysis of firm recommendations and consumer reviews in a competitive environment", Jabr, Wael and Eric Zheng. “ Know Yourself and Know Your Enemy: An Analysis of Firm Recommendations and Consumer Reviews in a Competitive Environment”. MIS Quarterly. Accepted July.

Kahneman, D. (1973), Attention and Effort, Citeseer.

Kim, H.-W., Xu, Y. and Koh, J. (2004), “A comparison of online trust building factors between potential customers and repeat customers", Journal of the Association for Information Systems, Vol. 5 No. 10, pp. $392-420$.

Kim, J.B. (2012), “An empirical study on consumer first purchase intention in online shopping: integrating initial trust and TAM", Electronic Commerce Research, Vol. 12 No. 2, pp. 125-150.

Koh, T.K., Fichman, M. and Kraut, R.E. (2012), “Trust across borders: Buyer-supplier trust in global Business-to-Business e-commerce”, Journal of the Association for Information Systems, Vol. 13 No. 11, pp. 886-922.

Kollock, P. (1999), “The economies ol online cooperation”, Communities in Cyberspace, Vol. 220.

Komiak, S.Y.X. and Benbasat, I. (2006), "The Effects of Personalization and Familiarity on Trust and Adoption of Recommendation Agents”, MIS Quarterly, Vol. 30 No. 4, pp. 941-960.

Kramer, R.M. (1999), “Trust and distrust in organizations: Emerging perspectives, enduring questions", Annual Review of Psychology, Annual Reviews 4139 El Camino Way, PO Box 10139, Palo Alto, CA 94303-0139, USA, Vol. 50 No. 1, pp. 569-598.

Lawrence, B., Fournier, S. and Brunel, F. (2013), “When Companies Don’t Make the Ad: A Multimethod Inquiry Into the Differential Effectiveness of Consumer-Generated Advertising”, Journal of 
Advertising, Taylor \& Francis, Vol. 42 No. 4, pp. 292-307.

Lee, M., Rodgers, S. and Kim, M. (2009), "Effects of valence and extremity of eWOM on attitude toward the brand and website", Journal of Current Issues \& Research in Advertising, Taylor \& Francis, Vol. 31 No. 2, pp. 1-11.

Lewicki, R.J., McAllister, D.J. and Bies, R.J. (1998), “Trust and distrust: New relationships and realities”, Academy of Management Review, Academy of Management, Vol. 23 No. 3, pp. 438-458.

Li, Y., Li, G. and Feng, T. (2015), "Effects of suppliers' trust and commitment on customer involvement”, Industrial Management \& Data Systems, Emerald Group Publishing Limited, Vol. 115 No. 6, pp. 1041-1066.

Luhmann, N. (1979), “Trust and power. 1979”, John Willey \& Sons.

Macrae, C.N. and Bodenhausen, G. V. (2001), “Social cognition: Categorical person perception”, British Journal of Psychology, Wiley Online Library, Vol. 92 No. 1, pp. 239-255.

McKnight, D.H., Choudhury, V. and Kacmar, C. (2002), "Developing and validating trust measures for ecommerce: an integrative typology", Information Systems Research, Vol. 13 No. 3, pp. 334-359.

Meyers-Levy, J. (1986), “Gender differences in information processing: A selectivity interpretation", Northwestern University.

Meyers-Levy, J. and Maheswaran, D. (1991), “Exploring differences in males' and females' processing strategies", Journal of Consumer Research, JSTOR, pp. 63-70.

Moore, G. and Benbasat, I. (1991), "Development of an instrument to measure the perceptions of adopting an information technology innovation", Information Systems Research, available at: http://pubsonline.informs.org/doi/abs/10.1287/isre.2.3.192 (accessed 24 February 2015).

Mudambi, S. and Schuff, D. (2010), "What makes a helpful review? A study of customer reviews on 
Amazon. com", MIS Quarterly, available at: http://papers.ssrn.com/sol3/papers.cfm?abstract_id=2175066 (accessed 16 February 2015).

Mukherjee, A. and Nath, P. (2007), "Role of electronic trust in online retailing”, European Journal of Marketing, Emerald, Vol. 41 No. 9/10, pp. 1173-1202.

Nadkarni, S. and Gupta, R. (2007), “A task-based model of perceived website complexity”, Mis Quarterly, available at: http://www.jstor.org/stable/25148805 (accessed 3 January 2015).

Ngai, E.W.T., Moon, K.K., Lam, S.S., Chin, E.S.K. and Tao, S.S.C. (2015), "Social media models, technologies, and applications: an academic review and case study", Industrial Management \& Data Systems, Emerald Group Publishing Limited, Vol. 115 No. 5, pp. 769-802.

Nunnally, J.C. and Bernstein, I.H. (1994), "Psychometric theory", New York McGraw-Hill.

Pan, L.-Y. and Chiou, J.-S. (2011), "How much can you trust online information? Cues for perceived trustworthiness of consumer-generated online information", Journal of Interactive Marketing, Elsevier, Vol. 25 No. 2, pp. 67-74.

Park, D.H. and Kim, S. (2008), "The effects of consumer knowledge on message processing of electronic word-of-mouth via online consumer reviews", Electronic Commerce Research and Applications, Vol. 7 No. 4, pp. $399-410$.

Park, D.H. and Lee, J.M. (2008), "eWOM overload and its effect on consumer behavioral intention depending on consumer involvement”, Electronic Commerce Research and Applications, Vol. 7 No. 4, pp. 386-398.

Pavlou, P.A. (2003), "Consumer acceptance of electronic commerce: Integrating trust and risk with the technology acceptance model”, International Journal of Electronic Commerce, Taylor \& Francis, Vol. 7 No. 3, pp. 101-134.

Pavlou, P.A. and Fygenson, M. (2006), “Understanding and predicting electronic commerce adoption: An 
extension of the theory of planned behavior", MIS Quarterly, Vol. 30 No. 1, pp. 115-143.

Reichheld, F.F. and Schefter, P. (2000), "E-loyalty”, Harvard Business Review, Harvard Business School Publication Corp., Vol. 78 No. 4, pp. 105-113.

Schriesheim, C.A. (1979), “The similarity of individual directed and group directed leader behavior descriptions", Academy of Management Journal, Academy of Management, Vol. 22 No. 2, pp. 345355.

Shi, S. and Chow, W.S. (2015), "Trust development and transfer in social commerce: prior experience as moderator", Industrial Management \& Data Systems, Emerald Group Publishing Limited, Vol. 115 No. 7, pp. 1182-1203.

Sirdeshmukh, D., Singh, J. and Sabol, B. (2002), "Consumer trust, value, and loyalty in relational exchanges”, Journal of Marketing, American Marketing Association, Vol. 66 No. 1, pp. 15-37.

Sitkin, S.B. and Roth, N.L. (1993), “Explaining the limited effectiveness of legalistic 'remedies' for trust/distrust", Organization Science, INFORMS, Vol. 4 No. 3, pp. 367-392.

Sparks, B.A. and Browning, V. (2011), "The impact of online reviews on hotel booking intentions and perception of trust", Tourism Management, Elsevier, Vol. 32 No. 6, pp. 1310-1323.

Tan, C.-W., Benbasat, I. and Cenfetelli, R.T. (2008), "Building citizen trust towards e-government services: do high quality websites matter?", Hawaii International Conference on System Sciences, Proceedings of the 41st Annual, IEEE, p. 217.

Thompson, D. V and Malaviya, P. (2013), “Consumer-Generated Ads: Does Awareness of Advertising CoCreation Help or Hurt Persuasion?", Journal of Marketing, American Marketing Association, Vol. 77 No. 3, pp. 33-47.

Ulbrich, F., Christensen, T. and Stankus, L. (2011), "Gender-specific on-line shopping preferences", Electronic Commerce Research, Vol. 11 No. 2, pp. 181-199. 
Valvi, A.C. and Fragkos, K.C. (2012), "Critical review of the e-loyalty literature: a purchase-centred framework", Electronic Commerce Research, Vol. 12 No. 3, pp. 331-378.

Wang, S., Beatty, S.E. and Foxx, W. (2004), "Signaling the trustworthiness of small online retailers", Journal of Interactive Marketing, Wiley Online Library, Vol. 18 No. 1, pp. 53-69.

Warkentin, M., Gefen, D., Pavlou, P.A. and Rose, G.M. (2002), "Encouraging citizen adoption of egovernment by building trust”, Electronic Markets, Taylor \& Francis, Vol. 12 No. 3, pp. 157-162.

Wixom, B.H. and Watson, H.J. (2001), “An empirical investigation of the factors affecting data warehousing success", MIS Quarterly, JSTOR, pp. 17-41.

Yeh, J.-C., Hsiao, K.-L. and Yang, W.-N. (2012), “A study of purchasing behavior in Taiwan's online auction websites: Effects of uncertainty and gender differences", Internet Research, Emerald Group Publishing Limited, Vol. 22 No. 1, pp. 98-115.

Yen, H.R. (2006), "Risk-reducing signals for new online retailers: a study of single and multiple signalling effects", International Journal of Internet Marketing and Advertising, Inderscience, Vol. 3 No. 4, pp. 299-317. 


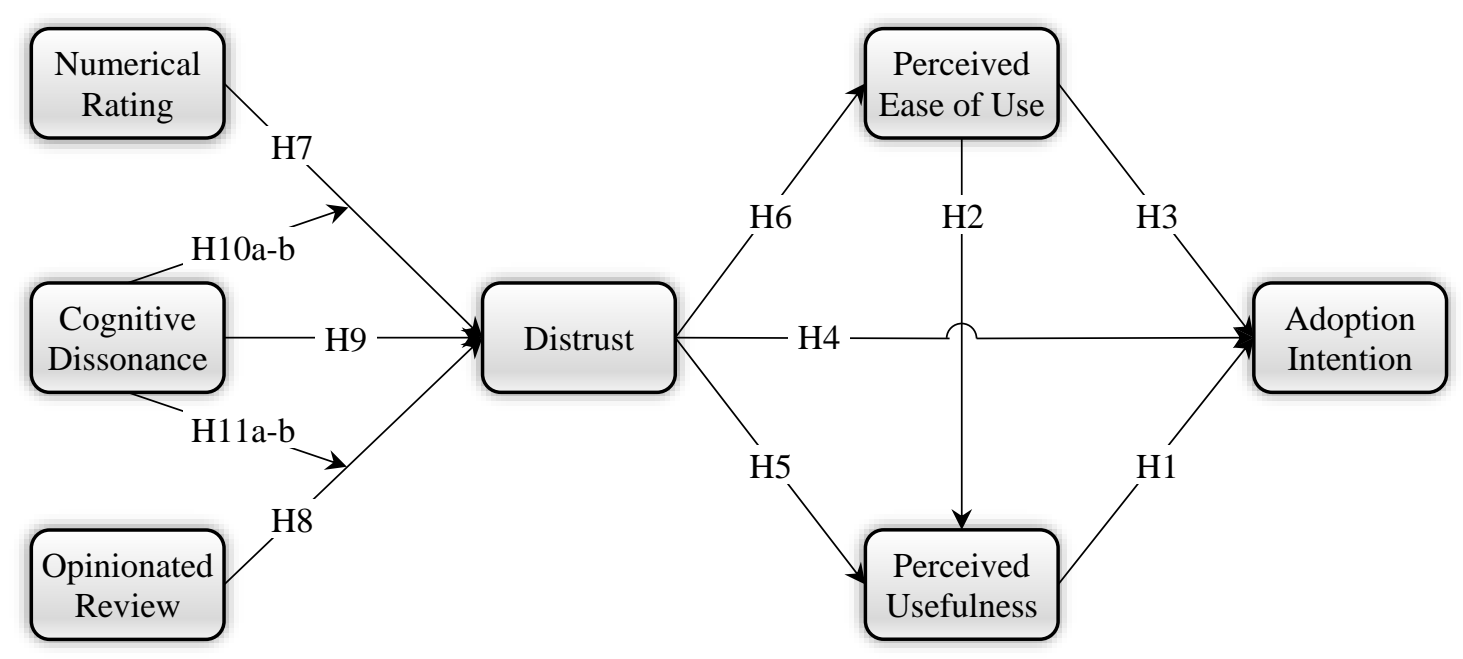

Figure 1. Research Framework

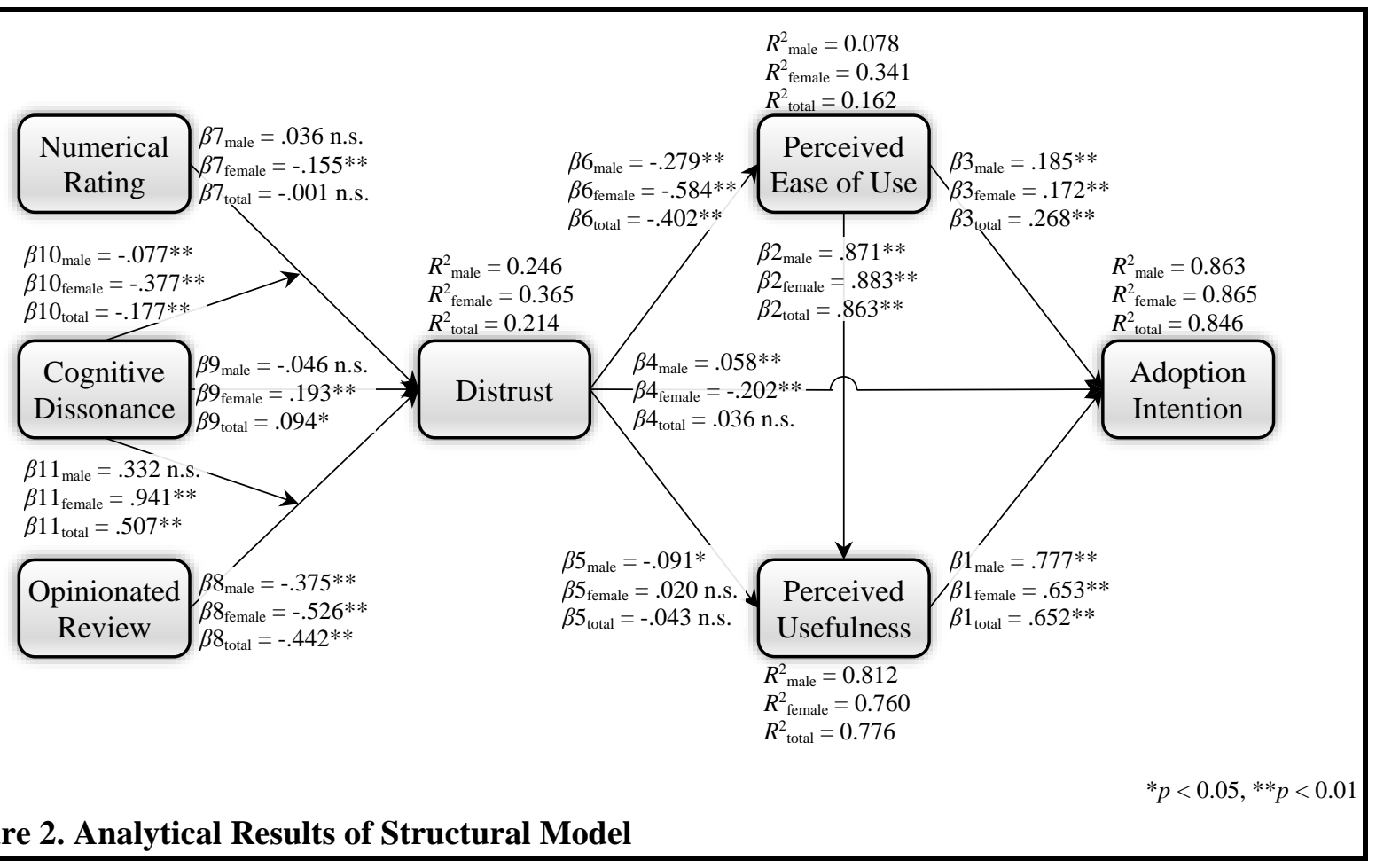




\begin{tabular}{|c|c|c|c|c|c|c|c|}
\hline \multirow[b]{2}{*}{ Construct } & \multirow[b]{2}{*}{ Reflective Measure } & \multicolumn{2}{|c|}{ Male $[N=57]$} & \multicolumn{2}{|c|}{ Female $[N=58]$} & \multicolumn{2}{|c|}{ Total $[N=115]$} \\
\hline & & $\begin{array}{l}\text { Mean } \\
\text { (S.D.) }\end{array}$ & $\begin{array}{c}\text { Item } \\
\text { Loading }\end{array}$ & $\begin{array}{l}\text { Mean } \\
\text { (S.D.) }\end{array}$ & $\begin{array}{c}\text { Item } \\
\text { Loading }\end{array}$ & $\begin{array}{l}\text { Mean } \\
\text { (S.D.) }\end{array}$ & $\begin{array}{c}\text { Item } \\
\text { Loading }\end{array}$ \\
\hline \multirow{3}{*}{$\begin{array}{l}\text { Numerical } \\
\text { Rating [NR] } \\
\text { (Newly } \\
\text { Developed) }\end{array}$} & $\begin{array}{l}\text { The online review website provides } \\
\text { numerical ratings assigned by other } \\
\text { consumers for each restaurant featured on } \\
\text { the site. }\end{array}$ & $\begin{array}{c}5.333 \\
(1.504)\end{array}$ & 0.934 & $\begin{array}{c}5.586 \\
(1.499)\end{array}$ & 0.879 & $\begin{array}{c}5.461 \\
(1.500)\end{array}$ & 0.893 \\
\hline & $\begin{array}{l}\text { The online review website provides } \\
\text { numerical scores assigned by other } \\
\text { consumers for each restaurant featured on } \\
\text { the site. }\end{array}$ & $\begin{array}{c}4.877 \\
(1.680)\end{array}$ & 0.913 & $\begin{array}{c}5.224 \\
(1.545)\end{array}$ & 0.952 & $\begin{array}{c}5.052 \\
(1.616)\end{array}$ & 0.945 \\
\hline & $\begin{array}{l}\text { The online review website provides } \\
\text { numerical values assigned by other } \\
\text { consumers for each restaurant featured on } \\
\text { the site. }\end{array}$ & $\begin{array}{c}5.053 \\
(1.540)\end{array}$ & 0.758 & $\begin{array}{c}5.069 \\
(1.599)\end{array}$ & 0.958 & $\begin{array}{c}5.061 \\
(1.563)\end{array}$ & 0.910 \\
\hline \multirow{5}{*}{$\begin{array}{l}\text { Opinionated } \\
\text { Review } \\
{[\mathrm{OR}]} \\
\text { (Newly } \\
\text { Developed) }\end{array}$} & $\begin{array}{l}\text { The online review website provides other } \\
\text { consumers' comments for each restaurant } \\
\text { featured on the site. }\end{array}$ & $\begin{array}{c}5.842 \\
(0.996)\end{array}$ & 0.845 & $\begin{array}{c}5.862 \\
(1.357)\end{array}$ & 0.933 & $\begin{array}{c}5.852 \\
(1.186)\end{array}$ & 0.903 \\
\hline & $\begin{array}{l}\text { The online review website provides other } \\
\text { consumers' feedback for each restaurant } \\
\text { featured on the site. }\end{array}$ & $\begin{array}{c}5.860 \\
(0.990)\end{array}$ & 0.794 & $\begin{array}{c}5.862 \\
(1.317)\end{array}$ & 0.925 & $\begin{array}{c}5.861 \\
(1.161)\end{array}$ & 0.878 \\
\hline & $\begin{array}{l}\text { The online review website provides other } \\
\text { consumers' impressions for each restaurant } \\
\text { featured on the site. }\end{array}$ & $\begin{array}{c}5.737 \\
(1.232)\end{array}$ & 0.877 & $\begin{array}{c}5.793 \\
(1.295)\end{array}$ & 0.936 & $\begin{array}{c}5.765 \\
(1.259)\end{array}$ & 0.906 \\
\hline & $\begin{array}{l}\text { The online review website provides other } \\
\text { consumers' opinions for each restaurant } \\
\text { featured on the site. }\end{array}$ & $\begin{array}{c}5.895 \\
(0.939)\end{array}$ & 0.875 & $\begin{array}{c}5.862 \\
(1.317)\end{array}$ & 0.952 & $\begin{array}{c}5.878 \\
(1.141)\end{array}$ & 0.921 \\
\hline & $\begin{array}{l}\text { The online review website provides other } \\
\text { consumers' views for each restaurant } \\
\text { featured on the site. }\end{array}$ & $\begin{array}{c}5.842 \\
(1.066)\end{array}$ & 0.762 & $\begin{array}{c}5.879 \\
(1.229)\end{array}$ & 0.946 & $\begin{array}{c}5.861 \\
(1.146)\end{array}$ & 0.876 \\
\hline \multirow{2}{*}{$\begin{array}{l}\text { Cognitive } \\
\text { Dissonance } \\
\text { [CD] } \\
\text { (Festinger, } \\
\text { 2010) }\end{array}$} & $\begin{array}{l}\text { Ratings and reviews on the online review } \\
\text { website are inconsistent with one another. }\end{array}$ & $\begin{array}{c}2.982 \\
(1.316)\end{array}$ & 0.998 & $\begin{array}{c}2.397 \\
(1.242)\end{array}$ & 0.928 & $\begin{array}{c}2.687 \\
(1.307)\end{array}$ & 0.959 \\
\hline & $\begin{array}{l}\text { Ratings and reviews on the online review } \\
\text { website are conflicting with one another. }\end{array}$ & $\begin{array}{c}2.842 \\
(1.115)\end{array}$ & 0.758 & $\begin{array}{c}2.690 \\
(1.259)\end{array}$ & 0.914 & $\begin{array}{c}2.765 \\
(1.187)\end{array}$ & 0.873 \\
\hline \multirow{4}{*}{$\begin{array}{l}\text { Distrust } \\
\text { [DT] (Cho, } \\
\text { 2006) }\end{array}$} & $\begin{array}{l}\text { I suspect that the online review website does } \\
\text { not perform its purpose honestly. }\end{array}$ & $\begin{array}{c}3.439 \\
(1.593)\end{array}$ & 0.952 & $\begin{array}{c}2.397 \\
(1.270)\end{array}$ & 0.916 & $\begin{array}{c}2.913 \\
(1.525)\end{array}$ & 0.944 \\
\hline & $\begin{array}{l}\text { I am concerned that the online review } \\
\text { website will act contrary to my best interests. }\end{array}$ & $\begin{array}{c}3.368 \\
(1.566) \\
\end{array}$ & 0.969 & $\begin{array}{c}2.362 \\
(1.195) \\
\end{array}$ & 0.968 & $\begin{array}{c}2.861 \\
(1.474) \\
\end{array}$ & 0.971 \\
\hline & $\begin{array}{l}\text { I suspect that the online review website will } \\
\text { exploit my vulnerabilities as a customer } \\
\text { given the chance. }\end{array}$ & $\begin{array}{c}3.333 \\
(1.443)\end{array}$ & 0.959 & $\begin{array}{c}2.379 \\
(1.268)\end{array}$ & 0.974 & $\begin{array}{c}2.852 \\
(1.434)\end{array}$ & 0.969 \\
\hline & I distrust the online review website. & $\begin{array}{c}3.246 \\
(1.515)\end{array}$ & 0.948 & $\begin{array}{c}2.345 \\
(1.193)\end{array}$ & 0.969 & $\begin{array}{c}2.791 \\
(1.430)\end{array}$ & 0.961 \\
\hline \multirow{3}{*}{$\begin{array}{l}\text { Perceived } \\
\text { Usefulness } \\
\text { [PU] (Gefen } \\
\text { et al., } \\
\text { 2003b) }\end{array}$} & $\begin{array}{l}\text { Using the online review website increases } \\
\text { the effectiveness of my decision making } \\
\text { process. }\end{array}$ & $\begin{array}{c}5.368 \\
(1.397)\end{array}$ & 0.967 & $\begin{array}{c}5.448 \\
(1.512)\end{array}$ & 0.975 & $\begin{array}{c}5.409 \\
(1.450)\end{array}$ & 0.971 \\
\hline & $\begin{array}{l}\text { Using the online review website improves } \\
\text { the performance of my decision making } \\
\text { process. }\end{array}$ & $\begin{array}{c}5.298 \\
(1.401)\end{array}$ & 0.959 & $\begin{array}{c}5.328 \\
(1.637)\end{array}$ & 0.977 & $\begin{array}{c}5.313 \\
(1.518)\end{array}$ & 0.969 \\
\hline & $\begin{array}{l}\text { Overall, the online review website is useful } \\
\text { towards my decision making process. }\end{array}$ & 5.404 & 0.968 & 5.534 & 0.982 & 5.470 & 0.975 \\
\hline
\end{tabular}




\begin{tabular}{|c|c|c|c|c|c|c|c|}
\hline & & $(1.237)$ & & $(1.635)$ & & $(1.447)$ & \\
\hline \multirow{4}{*}{$\begin{array}{l}\text { Perceived } \\
\text { Ease of Use } \\
{[\mathrm{PE}] \text { (Gefen }} \\
\text { et al., } \\
\text { 2003b) }\end{array}$} & $\begin{array}{l}\text { Using the online review website enables me } \\
\text { to quickly decide on which restaurant to } \\
\text { visit. }\end{array}$ & $\begin{array}{c}5.088 \\
(1.455)\end{array}$ & 0.916 & $\begin{array}{c}5.293 \\
(1.510)\end{array}$ & 0.781 & $\begin{array}{c}5.191 \\
(1.480)\end{array}$ & 0.852 \\
\hline & The online review website is easy to use. & $\begin{array}{c}5.228 \\
(1.500)\end{array}$ & 0.932 & $\begin{array}{c}5.328 \\
(1.669)\end{array}$ & 0.942 & $\begin{array}{c}5.278 \\
(1.581)\end{array}$ & 0.936 \\
\hline & $\begin{array}{l}\text { It is easy to become skillful at utilizing the } \\
\text { online review website. }\end{array}$ & $\begin{array}{c}5.421 \\
(1.463)\end{array}$ & 0.959 & $\begin{array}{c}5.466 \\
(1.441)\end{array}$ & 0.958 & $\begin{array}{c}5.443 \\
(1.446)\end{array}$ & 0.957 \\
\hline & $\begin{array}{l}\text { Learning to operate the online review } \\
\text { website is easy. }\end{array}$ & $\begin{array}{c}5.386 \\
(1.521)\end{array}$ & 0.931 & $\begin{array}{c}5.621 \\
(1.449)\end{array}$ & 0.892 & $\begin{array}{c}5.504 \\
(1.483)\end{array}$ & 0.909 \\
\hline \multirow{3}{*}{$\begin{array}{l}\text { Adoption } \\
\text { Intention } \\
\text { [AI] (Gefen } \\
\text { et al., } \\
\text { 2003b) }\end{array}$} & $\begin{array}{l}\text { I am willing to utilize the online review } \\
\text { website to help with my decisions about } \\
\text { which restaurant to visit. }\end{array}$ & $\begin{array}{c}5.386 \\
(1.373)\end{array}$ & 0.952 & $\begin{array}{c}5.707 \\
(1.364)\end{array}$ & 0.956 & $\begin{array}{c}5.548 \\
(1.372)\end{array}$ & 0.952 \\
\hline & $\begin{array}{l}\text { I am willing to let the online review website } \\
\text { assist me in deciding which restaurant to } \\
\text { visit. }\end{array}$ & $\begin{array}{c}5.316 \\
(1.525)\end{array}$ & 0.957 & $\begin{array}{c}5.569 \\
(1.464)\end{array}$ & 0.971 & $\begin{array}{c}5.443 \\
(1.494)\end{array}$ & 0.963 \\
\hline & $\begin{array}{l}\text { I am willing to rely on the online review } \\
\text { website in deciding which restaurant to visit. }\end{array}$ & $\begin{array}{c}5.333 \\
(1.406)\end{array}$ & 0.965 & $\begin{array}{c}5.310 \\
(1.501)\end{array}$ & 0.944 & $\begin{array}{c}5.322 \\
(1.448)\end{array}$ & 0.952 \\
\hline
\end{tabular}

\section{Table 2. Demographics of Respondents [N $=115$ ]}

\begin{tabular}{|c|c|c|c|}
\hline \multicolumn{2}{|r|}{ Demographic } & Number & Percentage \\
\hline \multirow{3}{*}{$\frac{\bar{d}}{\stackrel{D}{D}}$} & Male & 57 & $49.6 \%$ \\
\hline & Female & 58 & $50.4 \%$ \\
\hline & Unwilling to disclose & 0 & $0.0 \%$ \\
\hline \multirow{5}{*}{$\underset{\infty}{\infty}$} & Age 19 to 29 & 83 & $72.2 \%$ \\
\hline & Age 30 to 49 & 23 & $20.0 \%$ \\
\hline & Age 50 to 64 & 8 & $7.0 \%$ \\
\hline & Age $65+$ & 1 & $0.9 \%$ \\
\hline & Unwilling to disclose & 0 & $0.0 \%$ \\
\hline \multirow{3}{*}{ 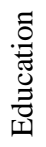 } & Less than college education & 14 & $12.2 \%$ \\
\hline & College education or higher & 100 & $87.0 \%$ \\
\hline & Unwilling to disclose & 1 & $0.9 \%$ \\
\hline \multirow{5}{*}{ 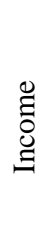 } & $\$ 0$ to $\$ 30,000$ & 79 & $68.7 \%$ \\
\hline & $\$ 30,000+$ to $\$ 50,000$ & 16 & $13.9 \%$ \\
\hline & $\$ 50,000+$ to $\$ 75,000$ & 8 & $7.0 \%$ \\
\hline & $\$ 75,000+$ & 5 & $4.3 \%$ \\
\hline & Unwilling to disclose & 7 & $6.1 \%$ \\
\hline
\end{tabular}




\begin{tabular}{|c|c|c|c|c|c|c|c|c|c|c|}
\hline \multicolumn{11}{|c|}{ Table 3. Internal Consistency and Inter-Construct Correlation } \\
\hline Construct & $\begin{array}{c}\text { Cronbach's } \alpha \\
{[>0.70]} \\
\end{array}$ & $\begin{array}{c}\text { CR } \\
{[>0.70]}\end{array}$ & $\begin{array}{c}\text { AVE } \\
{[>0.50]}\end{array}$ & NR & OR & CD & DT & PU & PE & AI \\
\hline $\begin{array}{c}\text { Numerical } \\
\text { Rating [NR] }\end{array}$ & $\begin{array}{l}\text { M: } 0.893 \\
\text { F: } 0.922 \\
\text { T: } 0.907\end{array}$ & $\begin{array}{l}\text { M: } 0.904 \\
\text { F: } 0.951 \\
\text { T: } 0.940\end{array}$ & $\begin{array}{l}\text { M: } 0.760 \\
\text { F: } 0.866 \\
\text { T: } 0.839\end{array}$ & $\begin{array}{c}\text { M: } 0.872 \\
\text { F: } 0.930 \\
\text { T: } 0.916\end{array}$ & & & & & & \\
\hline $\begin{array}{c}\text { Opinionated } \\
\text { Review } \\
{[\mathrm{OR}]}\end{array}$ & $\begin{array}{c}\text { M: } 0.890 \\
\text { F: } 0.966 \\
\text { T: } 0.940\end{array}$ & $\begin{array}{l}\text { M: } 0.918 \\
\text { F: } 0.974 \\
\text { T: } 0.954\end{array}$ & $\begin{array}{l}\text { M: } 0.692 \\
\text { F: } 0.880 \\
\text { T: } 0.805\end{array}$ & $\begin{array}{l}\text { M: } 0.485 \\
\text { F: } 0.441 \\
\text { T: } 0.461\end{array}$ & $\begin{array}{c}\text { M: } 0.832 \\
\text { F: } 0.938 \\
\text { T: } 0.897\end{array}$ & & & & & \\
\hline $\begin{array}{c}\text { Cognitive } \\
\text { Dissonance } \\
{[\mathrm{CD}]}\end{array}$ & $\begin{array}{l}\text { M: } 0.835 \\
\text { F: } 0.822 \\
\text { T: } 0.822 \\
\end{array}$ & $\begin{array}{l}\text { M: } 0.878 \\
\text { F: } 0.918 \\
\text { T: } 0.913\end{array}$ & $\begin{array}{l}\text { M: } 0.785 \\
\text { F: } 0.848 \\
\text { T: } 0.841\end{array}$ & $\begin{array}{c}\text { M: }-0.493 \\
\text { F: }-0.522 \\
\text { T: }-0.521 \\
\end{array}$ & $\begin{array}{c}\text { M: }-0.468 \\
\text { F: }-0.669 \\
\text { T: }-0.564\end{array}$ & $\begin{array}{c}\text { M: } 0.886 \\
\text { F: } 0.921 \\
\text { T: } 0.917 \\
\end{array}$ & & & & \\
\hline $\begin{array}{c}\text { Distrust } \\
\text { [DT] }\end{array}$ & $\begin{array}{l}\text { M: } 0.970 \\
\text { F: } 0.969 \\
\text { T: } 0.973\end{array}$ & $\begin{array}{l}\text { M: } 0.978 \\
\text { F: } 0.977 \\
\text { T: } 0.980\end{array}$ & $\begin{array}{l}\text { M: } 0.916 \\
\text { F: } 0.916 \\
\text { T: } 0.925\end{array}$ & $\begin{array}{l}\text { M: }-0.085 \\
F:-0.232 \\
\text { T: }-0.155\end{array}$ & $\begin{array}{l}\text { M: }-0.343 \\
F:-0.334 \\
\text { T: }-0.309\end{array}$ & $\begin{array}{l}\text { M: } 0.126 \\
\text { F: } 0.334 \\
\text { T: } 0.250\end{array}$ & $\begin{array}{c}\text { M: } 0.957 \\
\text { F: } 0.957 \\
\text { T: } 0.962\end{array}$ & & & \\
\hline $\begin{array}{l}\text { Perceived } \\
\text { Usefulness } \\
{[\mathrm{PU}]} \\
\end{array}$ & $\begin{array}{l}\text { M: } 0.962 \\
\text { F: } 0.977 \\
\text { T: } 0.970\end{array}$ & $\begin{array}{l}\text { M: } 0.976 \\
\text { F: } 0.985 \\
\text { T: } 0.981\end{array}$ & $\begin{array}{l}\text { M: } 0.930 \\
\text { F: } 0.957 \\
\text { T: } 0.944 \\
\end{array}$ & $\begin{array}{c}\text { M: } 0.376 \\
\text { F: } 0.387 \\
\text { T: } 0.383\end{array}$ & $\begin{array}{l}\text { M: } 0.637 \\
\text { F: } 0.182 \\
\text { T: } 0.348\end{array}$ & $\begin{array}{l}\text { M: }-0.508 \\
\text { F: }-0.398 \\
\text { T: }-0.458 \\
\end{array}$ & $\begin{array}{c}\text { M: }-0.334 \\
\text { F: }-0.496 \\
\text { T: }-0.390\end{array}$ & $\begin{array}{c}\text { M: } 0.964 \\
\text { F: } 0.978 \\
\text { T: } 0.972 \\
\end{array}$ & & \\
\hline $\begin{array}{l}\text { Perceived } \\
\text { Ease of Use } \\
{[\mathrm{PE}]}\end{array}$ & $\begin{array}{l}\text { M: } 0.952 \\
\text { F: } 0.916 \\
\text { T: } 0.934\end{array}$ & $\begin{array}{l}\text { M: } 0.965 \\
\text { F: } 0.942 \\
\text { T: } 0.953\end{array}$ & $\begin{array}{l}\text { M: } 0.874 \\
\text { F: } 0.803 \\
\text { T: } 0.836\end{array}$ & $\begin{array}{l}\text { M: } 0.342 \\
\text { F: } 0.481 \\
\text { T: } 0.431\end{array}$ & $\begin{array}{l}\text { M: } 0.605 \\
\text { F: } 0.315 \\
\text { T: } 0.429\end{array}$ & $\begin{array}{l}\text { M: }-0.497 \\
\text { F: }-0.516 \\
\text { T: }-0.520\end{array}$ & $\begin{array}{c}\text { M: }-0.279 \\
\text { F: }-0.584 \\
\text { T: }-0.402\end{array}$ & $\begin{array}{c}\text { M: } 0.897 \\
\text { F: } 0.872 \\
\text { T: } 0.880\end{array}$ & $\begin{array}{c}\text { M: } 0.935 \\
\text { F: } 0.896 \\
\text { T: } 0.914\end{array}$ & \\
\hline $\begin{array}{c}\text { Adoption } \\
\text { Intention } \\
{[\mathrm{AI}]}\end{array}$ & $\begin{array}{c}\text { M: } 0.955 \\
\text { F: } 0.954 \\
\text { T: } 0.953\end{array}$ & $\begin{array}{c}\text { M: } 0.971 \\
F: 0.970 \\
\text { T: } 0.969\end{array}$ & $\begin{array}{c}\text { M: } 0.917 \\
\text { F: } 0.916 \\
\text { T: } 0.914\end{array}$ & $\begin{array}{c}\text { M: } 0.361 \\
F: 0.355 \\
\text { T: } 0.366\end{array}$ & $\begin{array}{l}\text { M: } 0.633 \\
\text { F: } 0.228 \\
\text { T: } 0.388\end{array}$ & $\begin{array}{l}\text { M: }-0.425 \\
\text { F: }-0.447 \\
\text { T: }-0.463\end{array}$ & $\begin{array}{l}\text { M: }-0.253 \\
\text { F: }-0.627 \\
\text { T: }-0.416\end{array}$ & $\begin{array}{l}\text { M: } 0.924 \\
\text { F: } 0.903 \\
\text { T: } 0.909\end{array}$ & $\begin{array}{c}\text { M: } 0.866 \\
F: 0.859 \\
\text { T: } 0.863\end{array}$ & $\begin{array}{c}\text { M: } 0.958 \\
\text { F: } 0.957 \\
\text { T: } 0.956\end{array}$ \\
\hline
\end{tabular}

Note: $\mathrm{M} \rightarrow$ Male $[N=57] ; \mathrm{F} \rightarrow$ Female $[N=58] ; \mathrm{T} \rightarrow$ Total $[N=115]$. 


\section{Table 4. Summary of Hypothesis Testing}

\begin{tabular}{|c|c|c|c|c|c|c|c|}
\hline \multirow{2}{*}{ Hypothesis } & \multicolumn{2}{|c|}{ Male $[N=57]$} & \multicolumn{2}{|c|}{ Female $[N=58]$} & \multicolumn{2}{|c|}{ Total $[N=115]$} & \multirow{2}{*}{ Supported } \\
\hline & $\boldsymbol{\beta}$ & $t$-test & $\beta$ & $t$-test & $\beta$ & $t$-test & \\
\hline $\begin{array}{l}\text { H1: A consumer's perceived usefulness of an } \\
\text { online service provider positively influences } \\
\text { his/her intention to transact with the service } \\
\text { provider. }\end{array}$ & 0.777 & $21.601 * *$ & 0.653 & $19.215^{* *}$ & 0.652 & $15.048 * *$ & $\begin{array}{c}\text { Fully } \\
\text { Supported }\end{array}$ \\
\hline $\begin{array}{l}\text { H2: A consumer's perceived ease of use of an } \\
\text { online service provider positively influences } \\
\text { his/her perceived usefulness of the service } \\
\text { provider. }\end{array}$ & 0.871 & $47.002 * *$ & 0.883 & $36.133 * *$ & 0.863 & $46.542 * *$ & $\begin{array}{c}\text { Fully } \\
\text { Supported }\end{array}$ \\
\hline $\begin{array}{l}\text { H3: A consumer's perceived ease of use of an } \\
\text { online service provider positively influences } \\
\text { his/her intention to transact with the service } \\
\text { provider. }\end{array}$ & 0.185 & $4.519 * *$ & 0.172 & $4.326^{* *}$ & 0.268 & $5.723 * *$ & $\begin{array}{c}\text { Fully } \\
\text { Supported }\end{array}$ \\
\hline $\begin{array}{l}\text { H4: A consumer's distrust of an online service } \\
\text { provider negatively influence his/her intention } \\
\text { to transact with the service provider. }\end{array}$ & 0.058 & $3.509 * *$ & -0.202 & $7.114 * *$ & -0.054 & $2.104 *$ & $\begin{array}{c}\text { Partially } \\
\text { Supported }\end{array}$ \\
\hline $\begin{array}{l}\text { H5: A consumer's distrust of an online service } \\
\text { provider negatively influence his/her perceived } \\
\text { usefulness of the service provider. }\end{array}$ & -0.091 & $4.365 * *$ & 0.020 & 0.834 n.s. & -0.043 & 1.776 n.s. & $\begin{array}{c}\text { Partially } \\
\text { Supported }\end{array}$ \\
\hline $\begin{array}{l}\text { H6: A consumer's distrust of an online service } \\
\text { provider negatively influence his/her perceived } \\
\text { ease of use of the service provider. }\end{array}$ & -0.279 & $5.269 * *$ & -0.584 & $16.693 * *$ & -0.402 & $8.550 * *$ & $\begin{array}{c}\text { Fully } \\
\text { Supported }\end{array}$ \\
\hline $\begin{array}{l}\text { H7: e-WOM in the form of numerical rating } \\
\text { provided by an online service provider } \\
\text { negatively influences a consumer's distrust of } \\
\text { the service provider. }\end{array}$ & 0.036 & 0.477 n.s. & -0.155 & $3.339 * *$ & -0.001 & 0.041 n.s. & $\begin{array}{c}\text { Partially } \\
\text { Supported }\end{array}$ \\
\hline $\begin{array}{l}\text { H8: e-WOM in the form of opinionated review } \\
\text { provided by an online service provider } \\
\text { negatively influences a consumer's distrust of } \\
\text { the service provider. }\end{array}$ & -0.375 & $5.108 * *$ & -0.526 & $8.578 * *$ & -0.442 & $9.099 * *$ & $\begin{array}{c}\text { Fully } \\
\text { Supported }\end{array}$ \\
\hline $\begin{array}{l}\text { H9: A consumer's perception of cognitive } \\
\text { dissonance between numerical rating and } \\
\text { opinionated review offered by an online service } \\
\text { provider positively influences his/her distrust of } \\
\text { the service provider. }\end{array}$ & -0.046 & 1.016 n.s. & 0.193 & $3.751 * *$ & 0.094 & $2.039^{*}$ & $\begin{array}{c}\text { Partially } \\
\text { Supported }\end{array}$ \\
\hline $\begin{array}{l}\text { H10a: For a male consumer, his perception of } \\
\text { cognitive dissonance between numerical rating } \\
\text { and opinionated review offered by an online } \\
\text { service provider attenuates the negative } \\
\text { relationship between numerical rating and his } \\
\text { distrust of the service provider. }\end{array}$ & -0.077 & $6.141 * *$ & N/A & N/A & -0.177 & $2.017 *$ & $\begin{array}{c}\text { Not } \\
\text { Supported }\end{array}$ \\
\hline $\begin{array}{l}\text { H10b: For a female consumer, her perception of } \\
\text { cognitive dissonance between numerical rating } \\
\text { and opinionated review offered by an online } \\
\text { service provider reinforces the negative } \\
\text { relationship between numerical rating and her } \\
\text { distrust of the service provider. }\end{array}$ & N/A & N/A & -0.377 & $1.966^{*}$ & -0.177 & $2.017 *$ & $\begin{array}{c}\text { Fully } \\
\text { Supported }\end{array}$ \\
\hline $\begin{array}{l}\text { H11a: For a male consumer, his perception of } \\
\text { cognitive dissonance between numerical rating } \\
\text { and opinionated review offered by an online } \\
\text { service provider reinforces the negative } \\
\text { relationship between opinionated review and his } \\
\text { distrust of the service provider. }\end{array}$ & 0.332 & 1.708 n.s. & N/A & N/A & 0.507 & $3.824 * *$ & $\begin{array}{c}\text { Not } \\
\text { Supported }\end{array}$ \\
\hline
\end{tabular}


H11b: For a female consumer, her perception of cognitive dissonance between numerical rating and opinionated review offered by an online service provider attenuates the negative relationship between opinionated review and her distrust of the service provider.

\begin{tabular}{|l|l|l|l|l|l|l|}
\hline N/A & N/A & 0.941 & $3.330 * *$ & 0.507 & $3.824 * *$ & $\begin{array}{c}\text { Fully } \\
\text { Supported }\end{array}$ \\
\hline
\end{tabular}




\begin{tabular}{|c|c|c|c|c|c|c|c|}
\hline Table 5. Predictive Validity of the Structural Model \\
\hline \multirow{2}{*}{ Endogenous Construct } & \multicolumn{2}{|c|}{ Male $[\boldsymbol{N}=\mathbf{5 7}]$} & \multicolumn{1}{|c|}{ Female $[\boldsymbol{N = 5 8}]$} & \multicolumn{2}{|c|}{ Total $[\boldsymbol{N}=\mathbf{1 1 5}]$} \\
\cline { 2 - 8 } & $\mathbf{R}^{\mathbf{2}}$ & $\mathbf{Q}^{\mathbf{2}}$ & $\mathbf{R}^{\mathbf{2}}$ & $\mathbf{Q}^{\mathbf{2}}$ & $\mathbf{R}^{\mathbf{2}}$ & $\mathbf{Q}^{\mathbf{2}}$ \\
\hline Distrust [DT] & 0.246 & 0.236 & 0.365 & 0.326 & 0.214 & 0.192 \\
\hline Perceived Usefulness [PU] & 0.812 & 0.744 & 0.760 & 0.244 & 0.776 & 0.719 \\
\hline Perceived Ease of Use [PE] & 0.078 & 0.068 & 0.341 & 0.706 & 0.162 & 0.124 \\
\hline Adoption Intention [AI] & 0.863 & 0.748 & 0.865 & 0.765 & 0.846 & 0.734 \\
\hline
\end{tabular}

